\title{
PENGARUH KEPEMIMPINAN KEPALA SEKOLAH, KINERJA GURU, KOMITE SEKOLAH TERHADAP KEEFEKTIFAN SDN SE-KECAMATAN MLATI
}

\author{
Rahmat Pandoyo Susanto, Wuradji \\ SDN Sinduadi Timur, Universitas Negeri Yogyakarta \\ rpandoyo@yahoo.co.id
}

\begin{abstract}
Abstrak
Penelitian ini bertujuan untuk mengetahui pengaruh implementasi kepemimpinan kepala sekolah, kinerja guru, dan kinerja komite sekolah secara parsial maupun bersama-sama terhadap keefektifan sekolah di sekolah dasar negeri se-kecamatan Mlati Kabupaten Sleman. Populasi penelitian adalah 31 sekolah dasar negeri se-kecamatan Mlati Kabupaten Sleman, yang terdiri dari guru, dengan responden sebanyak 151 orang guru. Pemilihan responden menggunakan teknik proportional random sampling. Teknik pengumpulan data menggunakan angket dengan model Rating Scale. Uji validitas dan reliabilitas instrumen menggunakan rumus Alpha Cronbach's. Teknik analisis data dalam penelitian ini menggunakan analisis deskriptif, regresi sederhana, regresi ganda dengan taraf signifikan 5\%. Hasil analisis penelitian menunjukkan bahwa: (1) terdapat pengaruh yang positif dan signifikan variabel kepemimpinan kepala sekolah terhadap keefektifan sekolah; (2) terdapat pengaruh yang positif dan signifikan variabel kinerja guru terhadap keefektifan sekolah; (3) terdapat pengaruh yang positif dan signifikan kinerja komite sekolah terhadap keefektifan sekolah; (4) terdapat pengaruh positif dan signifikan secara bersama-sama variabel kepemimpinan partisipatif kepala sekolah, kinerja guru, dan kinerja komite sekolah terhadap keefektifan sekolah.
\end{abstract}

Kata kunci: kepemimpinan, kinerja, dan keefektifan sekolah.

\section{THE INFLUENCE OF PRINCIPALS' LEADERSHIP, TEACHERS' PERFORMANCE, SCHOOL COMMITTEE ON PUBLIC ELEMENTARY SCHOOL EFFECTIVENESS IN MLATI DISTRICT}

\author{
Rahmat Pandoyo Susanto, Wuradji \\ SDN Sinduadi Timur, Universitas Negeri Yogyakarta \\ rpandoyo@yahoo.co.id
}

\begin{abstract}
This study aims to idetermine the partial and simultaneous effects of principals' participatory leadership, teachers' performance, and school committees' performance on the school effectiveness in state elementary schools in Mlati District, Sleman Regency. The research population comprised 31 public elementary school in public elementary schools in Mlati District, Sleman Regency. The consisting of respondents 151 teachers, was selected of respondents by means of the proportional random sampling technique. The data were collected using a questionnaire of the Likert scale model. The instrument validity and reliability were assessed using the Cronbach's Alpha formula. The data were analyzed by means of the descriptive technique, simple regression, and multiple regression at a significance level of 5\%.The results of the simple regression analysis show that: (1) there is a significant positive effect of the variable of principals' participatory leadership on the school effectiveness; (2) there is a significant positive effect of the variable of teachers' performance on the school effectiveness; (3) there is a significant positive effect of the variable of school committees' performance on the school effectiveness; (4) the results of the multiple regression analysis show that there is a simultaneous significant positive effect of the variables of principals' participatory leadership, teachers' performance, and school committees' performance on the school effectiveness.
\end{abstract}

Keywords: leadership, performance, school effectiveness 



\section{Pendahuluan}

Salah satu masalah yang sangat serius dalam bidang pendidikan saat ini adalah rendahnya mutu pendidikan diberbagai jenis dan jenjang pendidikan. Hal itu tampak terlihat dengan semakin berkurangnya efektifitas pada sekolah dasar negeri. Banyak pihak berpendapat bahwa rendahnya mutu pendidikan merupakan salah satu faktor yang menghambat penyediaan sumber daya manusia yang mempunyai keahlian dan keterampilan untuk memenuhi tuntutan pembangunan di berbagai bidang.

Pemerintah selaku penyelenggara Pemerintah berkeyakinan bahwa dengan meningkatkan mutu input maka dengan sendirinya akan dapat meningkatkan mutu output. Dengan keyakinan tersebut, kebijakan dan upaya yang ditempuh pemerintah adalah pengadaan sarana dan prasarana pendidikan, pengadaan guru, menata para guru, dan menyediakan dana operasional pendidikan secara lebih memadai. Kenyataan tersebut memberi gambaran umum bahwa pendekatan input dan output secara makro belum menjamin peningkatan mutu sekolah dalam rangka meningkatkan dan meratakan mutu pendidikan

Peningkatan efektifitas sekolah sangat dipengaruhi oleh kepemimpinan kepala sekolah dalam mengatur jalannya roda pendidikan di sekolah. Kepemimpinan kepala sekolah yang efektif mampu menumbuhkan komitmen yang kuat untuk mencapai tujuan pendidikan di sekolah. Kepemimpinan kepala sekolah yang mempunyai kinerja yang baik maka efektifitas sekolah yang dipimpinnya menjadi efektif. Sebaliknya Kepala sekolah yang mempunyai kinerja yang kurang baik, maka efektifitas sekolah yang dipimpinnya kurang efektif. Dengan kata lain kepemimpinan sekolah merupakan salah satu faktor yang menentukan dalam keefektifan sekolah (Standar Kompetensi Kepala Sekolah, 2007, p.102)

Keefektifan sekolah merupakan salah satu kunci keberhasilan sekolah. Karena keefektifan sekolah sangat penting agar proses kegiatan belajar mengajar dapat berjalan dengan baik dan lancar untuk mencapai tujuan yang telah direncanakan oleh sekolah, sebaliknya tujuan sekolah tidak akan tercapai jika komponen-komponen yang berada di lingkungan sekolah tidak mengerti peran dan fungsi sekolah efektif (Harso, 2010, p. 3).

Keefektifan sekolah menuntut perubahan sikap dan tingkah laku dari seluruh komponen sekolah, baik kepala sekolah, guru maupun staf tata usaha, termasuk orang tua siswa dan masyarakat dalam memandang, memahami, dan membantu sekaligus mendorong dan mengevaluasi dalam pelaksanaan sekolah. Perubahan sikap dan tingkah laku tersebut dapat terjadi bila sumber daya sekolah yang ada dimanfaatkan dan dikelola secara optimal dan efektif kepala sekolah selaku orang yang bertanggung jawab dalam pelaksanaan pendidikan sekolah.

Peningkatan mutu sekolah dapat dilihat dari indikator, mutu masukan, mutu proses, mutu lulusan, mutu manajemen dan biaya. Kemampuan manajerial kepala sekolah sangat mendukung untuk meningkatkan mutu pendidikan di sekolah tersebut. Dengan demikian kepala sekolah dapat menjalankan tugas dan fungsi dengan sebaik-baiknya serta memainkan peran yaitu sebagai pemimpin sekaligus manajer agar sekolah yang dipimpin lebih efektif.

Penekanan keefektifan sekolah adalah proses belajar yang berlangsung secara aktif atau ada keterlibatan berbagai pihak terutama siswa dan guru sebagai subyek belajar. Namun demikian, sebagai lembaga, sekolah tidak hanya mengahadapi siswa, tetapi sumber daya lain yang patut diperhatikan kebutuhan, harapannya, dan aspirasinya. Pemikiran bahwa "siswa adalah segala-galanya" sangat pantas dikembangkan, tetapi dalam praktik manajemen tidak terlepas dari komponen-komponen yang membuat siswa menjadi segalagalanya.

Sekolah yang efektif adalah sekolah yang mengorganisasikan dan memanfaatkan semua sumber daya manusia yang dimilikinya untuk menjamin semua siswa bisa mempelajari materi kurikulum yang 
sesuai dengan ras, jenis kelamin, dan struktur ekonomi. Sekolah dasar sebagai lembaga pendidikan dasar mempunyai peran yang sangat penting untuk mewujudkan sekolah yang efektif. Karena efektifitas sekolah merupakan suatu cara untuk mencapai tujuan visi dan misi sekolah serta peningkatan mutu dalam pendidikan di sekolah dasar.

Dalam mewujudkan keefektifan sekolah kinerja guru sangat menentukan untuk mencapai tujuan mutu pendidikan. Guru dalam pendidikan mempunyai peran yang sangat sentral untuk mencapai keberhasilan mutu pendidikan. Dalam proses pendidikan yang berkualitas mensyaratkan kegiatan guru tentunya harus bernilai unggul. Semua komponen dalam proses belajar mengajar, materi, media, sarana dan prasarana, tidak banyak memberikan dukungan yang maksimal tanpa adanya keberadaan seorang guru. Hal ini dikarenakan keberadaan seorang guru yang terus-menerus selalu berupaya dan mendorong siswa untuk mencapai keberhasilan di dalam pendidikannya (Harso, 2010, p. 5).

Demikian halnya dengan keberadaan komite yang menjadi mitra kerja dari jalur luar sekolah sangat berperan mendukung dalam meningkatkan mutu pendidikan yang keberadaannya sangat strategis dalam membantu meningkatkan keefektifan sekolah. Dengan adanya komite yang selalu mendukung setiap kegiatan yang dilakukan oleh sekolah, maka menjadikan sekolah lebih dapat meningkatkan lagi dalam mencapai tujuan pendidikan yang telah direncanakan oleh sekolah. Namun dalam kenyataannya masih kita jumpai ada sebagian komite yang bersikap apatis tanpa melakukan tindakan apapun untuk menciptakan keefektifan sekolah.

Berkaitan dengan Keefektifan sekolah Cheng, (1996, p. 38) menyatakan ada delapan model keefektifan sekolah yaitu: (1) the goal model; (2) the resource input model; (3) the process model; (4) the satisfaction model; (5) the legitimacy model; (6) the ineffective model;(7) the organizational model; (8) The total management model.
Dari delapan model keefektifan sekolah tersebut dapat dijelaskan sebagai berikut: (1) merefleksikan tujuan yang penting dan yang prioritas dari kekuatan yang ada sehingga proses yang dinamis menjadi sangat nyaman; (2) keterbatasan sumber daya yang ada dari sekolah akan membatasi kemampuan untuk memaksimalkan efektivitas sekolah pada berbagai tingkat tujuan; (3) proses internal merefleksikan interaksi di antara pemilih internal dan eksternal yang penting untuk efektivitas sekolah; (4) menekankan pada perbedaan unsur pokok strategi untuk mempengaruhi bertahannya sekolah dan tujuan yang ingin dicapai; (5) berhubungan dengan pengakuan di masyarakat. Menekankan pada pentingnya paksaan dan tuntutan lingkungan, namun sekolah harus bisa bertahan; (6) menyediakan garis dasar untuk sekolah mengidentifikasi kejelasan saat situasi yang tidak seimbang pada proses pencapaian berbagai tujuan; (7) pada proses yang dinamis, kesadaran mengenai tekanan ketidak seimbangan dari paksaan lingkungan dan pilihan yang beragam serta adaptasi yang dinamis adalah kritikan untuk efektifitas sekolah jangka panjang; (8) model ini adalah gabungan model di atas khususnya organizational learning model, the satisfaction model, and the process model. Dengan kata lain, model ini menekankan pada perspektif yang holistik proses dinamis dari perebutan efektifitas sekolah.

Bosker \& Guldermon (Moerdiyanto, 2007, p. 6) mengembangkan sistem sekolah efektif yang terdiri dari lima komponen yaitu: Konteks, input, proses, output, dan outcome. Komponen konteks, misalnya adalah kebutuhan masyarakat, lingkungan sekolah, kebijakan pendidikan; komponen input misalnya adalah sumber daya dan kualitas guru. Komponen proses, misalnya adalah iklim sekolah dan kurikulum; dan komponen output misalnya, adalah hasil belajar siswa dan pencapaian keseluruhan. Sedangkan komponen outcome, adalah kesempatan kerja dan penghasilan.

Secara operasional dapat saja komponen keefektifan sekolah mengacu pada input, proses, dan outcome yang dikem- 
bangkan sesuai dengan kebutuhan, kondisi, serta keterbatasan yang ada model, teori, serta metodologi maupun hal-hal yang bersifat teknis. Komponen input sekolah ditinjau dari tiga aspek yaitu karakteristik sekolah, karakteristik guru, dan karakteristik siswa. Komponen proses ditinjau dari tiga aspek yaitu kepuasan kerja, guru, partisipasi orang tua siswa, dan iklim sekolah dan iklim sekolah. Komponen outcome terdiri dari dua aspek yaitu hasil belajar siswa dan konsep diri siswa.

Komariah \& Triatna (2010, p. 38) memperinci indikator efektif sebagai berikut: (1) tujuan sekolah dinyatakan dengan jelas dan spesifik, (2) pelaksanaan kepemimpinan yang kuat oleh kepala sekolah, (3) ekspektasi dari guru dan staf yang tinggi, (4) ada kerjasama kemitraan antara sekolah, orang tua siswa, dan masyarakat, (5) adanya iklim yang positif dan kondusif bagi siswa untuk belajar, (6) kemajuan siswa sering dimonitor, (7) menekankan kepada keberhasilan siswa dalam mencapai keterampilan aktivitas yang esensial, (8) komitmen yang tinggi dari SDM sekolah terhadap program pendidikan.

Pemimpin memiliki peranan yang dominan dalam sebuah organisasi. Peranan yang dominan tersebut dapat mempengaruhi moral kepuasan kerja keamanan, kualitas kehidupan kerja, dan terutama tingkat prestasi suatu organisasi.

Fattah (2004, p. 88) menyatakan bahwa Pemimpin adalah seseorang yang mempunyai kemampuan untuk mempengaruhi perilaku orang lain di dalam kerjanya dengan menggunakan kekuasaan. Kekuasaan adalah kemampuan mengarahkan dan mempengaruhi bawahan sehubungan dengan tugas-tugas yang harus dilaksanakannya.

Hoy \& Miskel (2008, p. 419) mengatakan "Leadership is a process of social influence in which one person is able to enlist the aid dan support of others in the accomplishment of a common task". Yang mempunyai arti kepemimpinan adalah proses pengaruh sosial di mana satu orang dapat meminta bantuan dan dukungan orang lain dalam pemenuhan tugas umum.
Lunenburg \& Ornstein (2000, p. 335) mengembangkan enam peran kepala sekolah yaitu: (1) promotoring quality instruction, (2) supervising and evaluating instruction, (3) allocating and protecting instuructional time, (4) coordinating the curriculum, (5) promoting content coverage, and (6) monitoring students Progress.

Wuradji (2009, p. 101) menyatakan bahwa: Peran kepala sekolah dalam penyelenggaraan pembelajaran merupakan peran yang paling tinggi bobotnya dibandingkan dengan dengan peran-peran yang lain. Hal ini cukup beralasan karena tugas utama sekolah adalah menyelenggarakan pendidikan dan pengajaran.

Robbins (terjemahan Bahasa Indonesia 1996, p. 58) mengatakan di dalam teori kepemimpinan ada empat fase pendekatan sebagai berikut. Pertama, Teori Kepemimpinan Atribusi. Teori ini mengemukakan bahwa kepemimpinan semata-mata suatu atribusi yang dibuat orang mengenai individu-individu lain. Kedua, Teori Kepemimpinan Karimastik. Teori ini mengemukakan bahwa pengikut membuat atribusi (penghubung) dari kemampuan kepemimpinan heroik atau luar biasa bila mereka mengamati perilaku-perilaku tertentu. Ketiga, Teori Kepemimpinan Transaksional. Teori ini mengemukakan bahwa seorang pemimpin transaksional adalah orang yang memandu atau memotivasi pengikut mereka dalam arah dan tujuan yang ditegaskan dengan memperjelas peran dan tuntutan tugas. Keempat, adalah Teori Kepemimpinan Transformasional. Teori ini mengemukakan bahwa seorang pemimpin memberikan pertimbangan dan rangsangan intelektual yang diindividualkan dan memiliki kharisma.

Nawawi (2006, p. 64) menyatakan bahwa: Kinerja adalah hasil kerja yang dicapai seseorang dalam melaksanakan tugas-tugas yang dibebankan kepadanya, berdasarkan kecakapan, pengalaman, kesungguhan, dan waktu. hasil kerja atau prestasi itu merupakan gabungan dari tiga faktor terdiri dari: (a) minat dalam bekerja, (b) penerimaan delegasi tugas, dan (c) peran dan tingkat motivasi seorang pekerja. 
Semakin tinggi/baik ketiga faktor tersebut dalam bekerja maka akan semakin besar/ baik prestasi kerja atau kinerja seorang pekerja/karyawan.

Wirawan (2009, p. 11) menyatakan bahwa: Evaluasi kinerja adalah sebagai proses penilai-pejabat yang melakukan penilaian- Apraiser mengumpulkan informasi mengenai kinerja ternilai (pegawai) yang didokumentasikan secara formal untuk menilai kinerja ternilai dengan membandingkannya dengan standar kinerjanya secara periodik untuk pengambilan keputusan manajemen SDM.

Sistem evaluasi kinerja guru hendaknya memberikan manfaat sebagai umpan balik untuk memenuhi berbagai kebutuhan di kelas (classroom needs). Selain itu dapat memberikan peluang bagi pengembangan teknis-teknis baru dalam pengajaran, serta mendapatkan konseling dari kepala sekolah, pengawas pendidikan atau guru lainnya untuk memberikan berbagai perubahan di dalam kelas.

Dalam buku pedoman Penilaian Kinerja Guru (Depdiknas, 2008, pp. 22-26) dinyatakan bahwa Alat Penilaian Kemampuan Guru (APKG) meliputi: (1) rencana pembelajaran (teaching plans and materials) atau disebut dengan RPP (Rencana Pelaksanaan Pembelajaran), (2) prosedur pembelajaran (classroom procedure), dan (3) hubungan antarpribadi (interpersonal skill) (Depdiknas, 2007, p. 22).

Dari Alat Penilaian Kemampuan Guru (APKG) tersebut disusun indikator penilaian terhadap kinerja guru dilakukan terhadap tiga kegiatan pembelajaran di kelas yaitu: (1) perencanaan program kegiatan pembelajaran; (2) pelaksanaan Kegiatan pembelajaran; (3) evaluasi/penilaian pembelajaran

Komite Sekolah adalah badan mandiri yang mewadahi peran serta masyarakat dalam rangka meningkatkan mutu, pemerataan, dan efesiensi pengelolaan pendidikan di satuan pendidikan baik dari jalur pendidikan prasekolah, jalur pendidikan sekolah maupun pendidikan luar sekolah.
Berdasarkan Keputusan Mendiknas No. 044/U/2002, peran dan fungsi komite sekolah tersebut di bawah ini. (1) Pemberi pertimbangan (advisory agency) dalam penentuan dan pelaksanaan pendidikan di satuan pendidikan; (2) Pendukung (supporting) baik yang berwujud finansial, pemikiran, maupun tenaga dalam penyelenggaran pendidikan di satuan pendidikan; (3) Pengontrol (controlling agency) dalam rangka transparansi dan akuntabilitas penyelenggaraan dan keluaran pendidikan di satuan pendidikan; (4) Mediator antara pemerintah (mediating) dengan masyarakat di satuan pendidikan.

Komite sekolah berfungsi sebagai berikut: (1) mendorong timbulnya perhatian dan komitmen masyarakat terhadap penyelenggaran pendidikan yang bermutu; (2) melakukan kerjasama dengan masyarakat (perorangan, organisasi/dunia usaha) dan pemerintah berkenaan dengan penyelenggaraan pendidikan yang bermutu; (3) menampung dan menganalisis aspirasi, ide, tuntutan, dan berbagai kebutuhan pendidikan yang diajukan oleh masyarakat; (4) Memberikan masukan pertimbangan dan merekomendasikan kepada satuan pendidikan mengenai: (a) kebijakan program pendidikan, (b) RAPBS (Rencana Anggaran Pendidikan dan Belanja Sekolah), (c) kriteria kinerja satuan pendidikan, (d) kriteria tenaga kependidikan, (e) kriteria fasilitas kependidikan, (f) hal-hal lain yang berkaitan dengan pendidikan; (5) mendorong orang tua dan masyarakat berpartisipasi dalam pendidikan guna mendukung peningkatan mutu dan pemerataan pendidikan; (6) menggalang dana masuyarakat dalam rangka pembiayaan penyelenggaraan pendidikan di satuan pendidikan; (7) melakukan evaluasi dan pengawasan terhadap kebijakan, program, penyelenggaraan, dan keluaran pendidikan di satuan pendidikan.

Berdasarkan uraian yang telah disampaikan, maka penelitian ini bertujuan untuk mengetahui pengaruh implementasi kepemimpinan kepala sekolah, kinerja gu$\mathrm{ru}$, dan kinerja komite sekolah secara parsial maupun bersama-sama terhadap keefek- 
tifan sekolah di sekolah dasar negeri sekecamatan Mlati Kabupaten Sleman.

\section{Metode Penelitian}

Jenis, Tempat, dan Waktu Penelitian

Penelitian ini merupakan penelitian survei tentang keefektifan sekolah sekolah dan faktor-faktor yang mempengaruhi di SDN Kecamatan Mlati. Di dalam penelitian ini pendekatan yang digunakan adalah pendekatan kuantitatif.

Penelitian dilakukan di sekolah dasar negeri di wilayah Unit pelayanan Teknis (UPT) Dinas Pendidikan dan Olah Raga kecamatan Mlati kabupaten Sleman. Penelitian ini akan dilaksanakan mulai bulan September 2013 sampai dengan bulan Januari tahun 2014, sesuai dengan perijinan dari kampus dan dinas terkait.

Populasi dan Responden Penelitian

Populasi dalam penelitian ini adalah seluruh SD di Kecamatan Mlati, Kabupaten Sleman berjumlah 31 SD.

Responden dalam penelitian sejumlah 430 guru yang dipilih dengan teknik simple random sampling. Teknik yang digunakan dalam penentuan responden berdasarkan tabel Krecjie \& Morgan didapat responden sejumlah 151 guru.

Variabel Penelitian

Variabel Terikat (Dependent Variable) Keefektifan Sekolah (Y)

Keefektifan sekolah dalam penelitian ini adalah performance sekolah yang ditampilkan oleh sekolah dalam mencapai tujuan baik kuantitas maupun kualitas yang tercermin dalam pelaksanaan kegiatan belajar mengajar. Sekolah efektif menunjukkan kesesuain hasil yang dicapai dengan hasil yang diharapkan. Hal ini terefleksi dalam kualitas sekolah, kepemimpinan kepala sekolah, lingkungan yang kondusif, kebijakan pendidikan yang efektif, visi dan misi sekolah yang visioner, jelas dan terarah, adanya sumber daya yang cukup memadai, kualitas guru yang profesional, sikap positif dan penguasaan mendalam terhadap pengajaran, harapan yang tinggi dari siswa, iklim sekolah yang nyaman, tertib bagi pelaksanaan pembelajaran, adanya pengorganisasian kurikulum yang mantap, serta proses belajar yang optimal untuk mencapai tujuan sekolah.

Variabel bebas (Independent Variable) Kepemimpinan Kepala Sekolah $\left(X_{1}\right)$

Kepemimpinan kepala sekolah dalam penelitian ini maksudnya adalah kemampuan kepala sekolah SD Negeri, untuk bersama-sama menyusun program sekolah, menggerakkan, mempengaruhi, membimbing, mengajak, memotivasi, dan mengarahkan dengan maksud agar dapat bekerja secara optimal untuk mencapai tujuan bersama-sama secara efektif dan efesien yang tercermin dalam kemampuannya sebagai manajer, leader, supervisor, menunjukkan keteladanan, dan menciptakan iklim kerja yang baik. Dalam hal ini ditunjukkan dengan keterbukaan, perhatian terhadap bawahan yang dipimpin, cara berkomunikasi, berinteraksi, dan cara pengambilan keputusan.

\section{Kinerja Guru $\left(\mathrm{X}_{2}\right)$}

Komitmen adalah rasa keterikatan yang Kinerja guru yang dimaksud dalam penelitian ini adalah merupakan prestasi atau pencapaian hasil kerja yang dicapai guru berdasarkan standar dan ukuran yang telah ditetapkan.Standar dan alat ukur tersebut merupakan indikator untuk menentukan apakah seorang guru berkinerja tinggi atau rendah. Perencanaan kinerja merupakan suatu proses di mana guru dan kepala sekolah bekerja sama merencanakan apa yang harus dikerjakan guru pada tahun mendatang, menentukan bagaimana kinerja harus diukur, mengenali, dan merumuskan cara mengatasi kendala, serta mencapai pemahaman bersama tentang pekerjaan itu. Kepala sekolah dan guru bekerja sama untuk saling berbagi informasi mengenai perkembangan kerja, hambatan, dan permasalahan, dan menanggulangi kesulitan atau persoalan sebelum itu menjadi besar. Kinerja guru merupakan salah satu faktor penentu dalam 
mendukung pencapaian tujuan keberhasilan sekolah.

\section{Kinerja Komite Sekolah $\left(X_{3}\right)$}

Kinerja komite sekolah dalam penelitian ini adalah: (1) pemberi pertimbangan (advisory agency) antara lain: perencanaan sekolah, pelaksanaan programkurikulum PBM dan penilaian, pengadaan sumber daya pendidikan (SDM dan anggaran); (2) Pendukung (supporting) antara lain: sumber daya, sarana dan prasarana, dan anggaran; (3) pengontrol (controlling agency) antara lain: kontrol terhadap perencanaan sekolah dan kontrol terhadap pelaksanaan program sekolah; (4) mediator antara pemerintah (mediating) antara lain: kontrol terhadap output pendidikan, perencanaan, dan pelaksanaan program.

\section{Teknik Pengumpulan Data}

Teknik pengumpulan data dalam penelitian ini yaitu angket. Data yang telah terkumpul kemudian dilakukan skala pengukuran dan pemberian skor. Skala pengukuran yang digunakan dalam penelitian ini adalah skala Rating Scale dengan pilihan skor 1 sampai 4 , yang menggunakan pernyataan tertutup dengan validitas item yang mendapat pertimbangan ahli dan uji empirik, sedangkan reliabilitas instrumen dengan teknik Alpha_Cronbach.

Adapun pengambilan keputusan pada uji validitas dengan menggunakan batasan $\mathrm{r}$ tabel, dengan signifikansi 0,05 atau menggunakan batasan 0,344 pada $n=$ 31. Hasil uji validitas instrumen variabel Keefektifan sekolah sekolah dari jumlah 20 item pertanyaan angket menunjukkan 19 item yang dianggap valid, instrumen variabel Kepemimpinan kepala sekolah dari 20 item pertanyaan angket menunjukkan 20 item dinyatakan valid, kemudian instrumen variabel kinerja guru dari 15 item pertanyaan angket menunjukkan 14 item dinyatakan valid, dan variabel kinerja komite sekolah dari 15 item pertanyaan angket menunjukkan 14 item dinyatakan valid.

Selanjutnya untuk uji reliabilitas, harga kritik untuk indeks reliabilitas instrumen adalah 0,6 hal ini berarti suatu instru- men dikatakan reliabel apabila memiliki alpha $>0,6$. Adapun hasil reliabiltas instrumen disajikan pada Tabel 1.

Tabel 1. Hasil Reliabilitas Instrumen

\begin{tabular}{lcc}
\hline \multicolumn{1}{c}{ Variabel } & $\begin{array}{c}\text { Cronbach's } \\
\text { Alpha }\end{array}$ & Keterangan \\
\hline Keefektifan Sekolah & 0,831 & Reliable \\
$\begin{array}{l}\text { Kepemimpian } \\
\text { Kepala Sekolah }\end{array}$ & 0,824 & Reliable \\
$\begin{array}{l}\text { Kinerja Guru } \\
\text { Kinerja Komite }\end{array}$ & 0,771 & Reliable \\
Sekolah & 0,759 & Reliable \\
\hline
\end{tabular}

Berdasarkan Tabel 1, semua instrumen dinyatakan reliabel. Semua instrumen yang dinyatakan valid dan reliabel sudah layak digunakan untuk mengambil data.

Teknis Analisis Data

\section{Analisis Data Deskriptif}

Untuk memberi deskripsi mengenai data penelitian, maka digunakan uji analisis deskripsi yang bertujuan untuk menganalisis data dengan cara mendeskripsikan atau menggambarkan data yang terkumpul, sebagaimana adanya. Analisis deskriptif ini digunakan untuk mendapatkan gambaran penyebaran hasil data hasil penelitian masing-masing variabel secara kategori. Analisis deskripsi menyangkut banyaknya subjek dalam kelompok, mean skor angket, deviasi standar skor angket, varians, skor maksimum, dan skor minimum.

\section{Uji Hipotesis}

Uji regresi sederhana untuk mengetahui pengaruh masing-masing variabel prediktor yang mempengaruhi budaya kepemimpinan kepala sekolah $\left(X_{1}\right)$ kinerja guru $\left(X_{2}\right)$ dan kinerja komite sekolah $\left(X_{3}\right)$ terhadap keefektifan sekolah $(\mathrm{Y})$ dengan menggunakan regresilinier berganda, yaitu: $\hat{Y}=a+b_{1} X_{1}+b_{2} X_{2}+\ldots+b_{n} X_{n}$

Keterangan :

$$
\begin{aligned}
& \mathrm{Y}=\text { nilai yang diprediksi } \\
& \mathrm{X}=\text { nilai variabel prediktor } \\
& \mathrm{a}=\text { bilangan konstan } \\
& \mathrm{b}=\text { bilangan koefisien prediktor }
\end{aligned}
$$




\section{Hasil Penelitian dan Pembahasan}

Analisis Deskriptif Variabel Penelitian

Analisis disikriptif variabel penelitian dapat dijelaskan bahwa variabel kepemimpinan kepala sekolah diperoleh mean sebesar 74,96 dengan standar deviasi sebesar
2,735. Variabel Kinerja Guru diperoleh mean sebesar 51,45 dengan standar deviasi sebesar 2,340, dan variabel kinerja komite sekolah diperoleh mean sebesar 51,70 dengan standar deviasi sebesar 2,452 serta keefektifan sekolah diperoleh mean 71,32 dengan standar deviasi sebesar 2,669.

Tabel 2. Rangkuman Diskripsi Data

\begin{tabular}{|c|c|c|c|c|c|}
\hline \multicolumn{6}{|c|}{ Statistics } \\
\hline & & $\begin{array}{l}\text { Kepemimpinan } \\
\text { Kepala Sekolah }\end{array}$ & Kinerja Guru & $\begin{array}{l}\text { Kinerja Komite } \\
\text { Sekolah }\end{array}$ & $\begin{array}{c}\text { Keefektifan } \\
\text { Sekolah }\end{array}$ \\
\hline \multirow[t]{2}{*}{$\mathrm{N}$} & Valid & 151 & 151 & 151 & 151 \\
\hline & Mising & 0 & 0 & 0 & 0 \\
\hline Mean & & 74,96 & 51,45 & 51,70 & 71,32 \\
\hline Median & & 75,00 & 52,00 & 52,00 & 72,00 \\
\hline Mode & & 75 & 52 & 52 & 72 \\
\hline Std. Deviation & & 2,735 & 2,340 & 2,452 & 2,669 \\
\hline Variance & & 7,478 & 5,476 & 6,011 & 7,125 \\
\hline Range & & 10 & 10 & 10 & -.325 \\
\hline Minimum & & 69 & 46 & 46 & 12 \\
\hline Maximum & & 79 & 56 & 56 & 64 \\
\hline Sum & & 11319 & 7769 & 7807 & 76 \\
\hline
\end{tabular}

Secara rinci dengan distribusi frekuensi deskripsi masing-masing variabel dijelaskan sebagai berikut:

\section{Keefektifan Sekolah}

Keefektifan sekolah dasar negeri sekecamatan Mlati sebagian besar memiliki kecenderungan yang tinggi. Hasil penelitian menunjukkan sebanyak 53 orang responden atau $53,10 \%$ dari seluruh responden pada kategori tinggi. Keefektifan sekolah pada kategori rendah hanya dicapai oleh 43 orang responden atau 28,50\% dari seluruh responden. Sementara kategori sangat tinggi hanya dicapai oleh 28 orang responden atau $18,50 \%$ dari seluruh responden. Sedangkan kategori sangat rendah dicapai oleh 27 orang responden atau sebesar $17,90 \%$ dari seluruh responden.

Tabel 3. Distribusi keefektifan Sekolah Dasar Negeri Se-kecamatan Mlati

\begin{tabular}{clccc}
\hline No & Kategori & Skor Interval & Frekuensi & $\%$ \\
\hline 1. & Sangat tinggi & $X>73,99$ & 28 & 18,50 \\
2. & Tinggi & $73,99>X>71,32$ & 53 & 35,10 \\
3. & Rendah & $71,31>X>68,65$ & 43 & 28,50 \\
4. & Sangat rendah & $X<68,64$ & 27 & 17,90 \\
& & & 151 & 1000 \\
\hline
\end{tabular}

Berdasarkan Tabel 2, mean atau skor rata-rata sebesar 71,32 terletak pada interval 71,32-73,99 dalam kategori tinggi. Hal ini mengandung arti bahwa kecenderungan jawaban responden secara keseluruhan mengarah pada tingkatan tinggi, dengan demikian, secara keseluruhan keefektifan Sekolah Dasar Negeri se-kecamatan Mlati dalam kategori tinggi

Kepemimpinan Kepala Sekolah

Kepemimpinan kepala sekolah dasar negeri se-kecamatan Mlati sebagian besar memiliki kecenderungan yang tinggi. Hasil penelitian menunjukkan sebanyak 63 orang responden atau $41,70 \%$ dari seluruh responden pada kategori tinggi. Kepemimpinan kepala sekolah pada kategori sangat tinggi dicapai oleh 32 orang responden atau $21,20 \%$ dari seluruh responden. Sementara pada kategori sangat rendah dicapai oleh 31 orang responden atau 20,50\% dari seluruh responden. Sedangkan kepemimpinan kepala sekolah pada kategori rendah dicapai 25 orang responden atau $16,60 \%$ dari seluruh responden.

Berdasarkan Tabel 4 mean atau skor rata-rata sebesar 74,96 terletak pada interval 74,96-77,69 dalam kategori tinggi, 
dengan demikian kepemimpinan kepala sekolah di sekolah dasar negeri se-kecamatan Mlati Kabupaten Sleman adalah tinggi. Hal ini mengandung arti bahwa kecenderungan jawaban responden secara keseluruhan mengarah pada tingkatan tinggi, dengan demikian, secara keseluruhan kepemimpinan kepala sekolah di sekolah dasar negeri se-kecamatan Mlati Kabupaten Sleman dalam kategori tinggi.

Tabel 4. Distribusi Kepemimpinan Kepala Sekolah

\begin{tabular}{llccc}
\hline No Kategori & Skor Interval & Frekuensi & $\%$ \\
\hline 1. Sangat tinggi & $X>77,69$ & 32 & 21,20 \\
2. Tinggi & $74,96>X>77,68$ & 63 & 41,70 \\
3. Rendah & $72,23>X>74,95$ & 25 & 16,60 \\
4. Sangat rendah & $X<72,22$ & 31 & 20,50 \\
& & 151 & 1000 \\
\hline
\end{tabular}

\section{Kinerja Guru}

Kinerja guru sekolah dasar negeri sekecamatan Mlati sebagian besar memiliki kecenderungan yang tinggi. Hasil penelitian menunjukkan sebanyak 52 orang responden atau $34,40 \%$ dari seluruh responden pada kategori tinggi. Kinerja guru pada kategori rendah dicapai oleh 41 orang responden atau $27,20 \%$ dari seluruh responden. Sementara kategori sangat rendah dicapai oleh 31 orang responden atau $20,50 \%$ dari seluruh responden. Sedangkan kinerja guru pada kategori sangat tinggi dicapai oleh 27 orang responden atau $17,90 \%$ dari seluruh responden.

Tabel 5. Distribusi Kinerja Guru Sekolah Dasar Negeri Se-kecamatan Mlati

\begin{tabular}{lccc}
\hline No. $\quad$ Kategori & Skor Interval & Frekuensi & $\%$ \\
\hline 1. Sangat tinggi & $X>53,79$ & 27 & 17,90 \\
2. Tinggi & $53,79>X>51,45$ & 52 & 34,40 \\
3. Rendah & $51,45>X>49,11$ & 41 & 27,20 \\
4. Sangat rendah & $X<49,11$ & 31 & 20,50 \\
& & 151 & 1000 \\
\hline
\end{tabular}

Pada Tabel 5 mean atau skor rata-rata variabel kinerja guru sebesar 51,45 terletak pada interval 51,45-53,79 dalam kategori tinggi, dengan demikian kinerja guru di sekolah dasar negeri se-kecamatan Mlati Kabupaten Sleman adalah tinggi. Hal ini mengandung arti bahwa kecenderungan jawaban responden secara keseluruhan mengarah pada tingkatan baik, dengan demikian, kinerja guru di sekolah dasar negeri se-kecamatan Mlati Kabupaten Sleman secara keseluruhan dalam kategori tinggi.

\section{Kinerja Komite Sekolah}

Kinerja komite sekolah dasar negeri se-kecamatan Mlati sebagian besar memiliki kecenderungan yang tinggi. Hasil penelitian menunjukkan sebanyak 57 orang responden atau $37,80 \%$ dari seluruh responden. Kinerja komite sekolah pada kategori sangat rendah dicapai oleh 37 orang responden atau $24,50 \%$ dari seluruh responden. Sementara kategori rendah dicapai oleh 27 orang responden atau $24,50 \%$ dari seluruh responden. Sedangkan kategori sangat tinggi dicapai oleh 20 orang responden atau 13,20\% dari seluruh responden.

Tabel 6. Distribusi Kinerja Komite Sekolah

\begin{tabular}{lcccc}
\hline No Kategori & Skor Interval & Frekuensi & $\%$ \\
\hline 1. & Sangat tinggi & $X>54,16$ & 37 & 24,50 \\
2. Tinggi & $54,15>X>51,70$ & 57 & 37,80 \\
3. Rendah & $51,69>X>49,25$ & 37 & 24,50 \\
4. Sangat rendah & $X<49,24$ & 20 & 13,20 \\
& & & 151 & 1000 \\
\hline
\end{tabular}

Dengan Tabel 2 dan berdasarkan Tabel 6, mean atau skor rata-rata variabel iklim organisasi sekolah sebesar 51,70 terletak pada interval 51,70-54,15 dalam kategori tinggi, dengan demikian iklim organisasi sekolah di sekolah dasar negeri sekecamatan Mlati Kabupaten Sleman adalah tinggi. Hal ini mengandung arti bahwa kecenderungan jawaban responden secara keseluruhan mengarah pada tingkatan tinggi, dengan demikian, iklim organisasi sekolah di sekolah dasar negeri se-kecamatan Mlati Kabupaten Sleman secara keseluruhan dalam kategori tinggi. 
Uji Hipotesis

\section{Analisis Regresi Linier Ganda}

Analisis pengujian hipotesis menggunakan regresi linier ganda. Hasil analisis meliputi uji kelayakan model koefisien regresi. Pengambilan keputusan menggunakan taraf signifikansi $p<0,05$. Sebuah model dan koefisien regresi dinyatakan signifikan jika memiliki nilai $\mathrm{p}<0,05$. Berikut ini hasil uji kelayakan model regresi:

Tabel 7. Hasil Model Anova Uji

Signifikansi Regresi Linier Ganda

ANOVA

\begin{tabular}{|c|c|c|c|c|c|}
\hline Model & $\begin{array}{l}\text { Sum of } \\
\text { Squares }\end{array}$ & $\mathrm{df}$ & $\begin{array}{c}\text { Mean } \\
\text { Square }\end{array}$ & $\mathrm{F}$ & Sig. \\
\hline \multirow[t]{3}{*}{1} & Regression & 865,391 & 1 & 865,391 &, $000^{a}$ \\
\hline & Residual & 203,351 & 149 & 1,365 & \\
\hline & Total & 1068,742 & 150 & & \\
\hline
\end{tabular}

Berdasarkan hasil uji Anova pada Tabel 8 di atas, dihasilkan $\mathrm{F}$ hitung = 962,587 dan sig. $=0,000$. Oleh karena $p<$ 0,05, maka diputuskan bahwa model regresi signifikan dan dapat digunakan untuk memprediksi keefektifan sekolah dasar di sekolah sekolah dasar negeri sekecammatan Mlati Kabupaten Sleman.

Besarnya pengaruh kepemimpinan kepala sekolah, kinerja guru, dan kinerja komite sekolah dapat dilihat pada output komputer berikut:

\section{Uji Koefisien Determinasi $\left(R^{2}\right)$}

Koefesien determinasi ganda $\left(\mathrm{R}^{2}\right.$ atau $\mathrm{R}$ Square) digunakan untuk mengukur sumbangan dari variabel kepemimpinan kepala sekolah (X1), kinerja guru (X2), dan kinerja komite sekolah (X3) terhadap keefektifan sekolah (Y) secara bersama-sama besarnya koefesien determinasi ganda $\left(R^{2}\right)$ berada di antara 0 dan 1 atau $0<\left(R^{2}\right)<1$. Semakin besar $R^{2}$ yang diperoleh dari perhitungan (mendekati 1), maka dapat dikatakan bahwa sumbangan dari varibel bebas terhadap variabel terikat semakin besar. Sebaliknya jika $\mathrm{R}^{2}$ yang diperoleh dari perhitungan (mendekati 0), maka dapat dikatakan sumbangan dari variabel kepemimpinan kepala sekolah (X1), kinerja guru (X2), dan kinerja komite sekolah (X3) semakin kecil. Hasil uji diterminasi $\left(\mathrm{R}^{2}\right)$ dapat dilihat pada Tabel 8 .

Tabel 8. Rangkuman Hasil Uji Koefesien Diterminasi $\left(R^{2}\right)$

\begin{tabular}{ccccccccc}
\multicolumn{10}{c}{ Summary } \\
\hline Model & $\mathrm{R}$ & R Square & $\begin{array}{c}\text { Adjusted } \\
\text { R Square }\end{array}$ & $\begin{array}{c}\text { Std. Error of } \\
\text { the Estimate }\end{array}$ & & $\begin{array}{c}\text { R Square } \\
\text { Change }\end{array}$ & F Change & Sig. F Change \\
\hline 1 & & $.951^{\text {a }}$ & .904 & .902 & .836 & .904 & 460.735 & .000 \\
\hline
\end{tabular}

Nilai adjusted $R^{2}$ yang ditunjukkan pada tabel 8 sebesar 0,902 . Artinya variabel kepemimpinan kepala sekolah (X1), kinerja guru (X2,), dan kinerja komite sekolah (X3) mampu menjelaskan sebesar $90,20 \%$ variasi yang ada pada variabel keefektifan sekolah atau dengan kata lain menjelaskan sebesar $90,20 \%$ perubahan yang terjadi pada variabel keefektifan sekolah. Sisanya sebesar $9,80 \%$. Dijelaskan oleh faktor-faktor lain.

\section{Uji Hipotesis Parsial}

Untuk mengetahui hubungan antarvariabel bebas dan variabel terikat maka dilakukan uji parsial. Uji parsial dilakukan untuk melihat ada tidaknya pengaruh kepemimpinan kepala sekolah, kinerja guru, dan kinerja komite sekolah. Hasil uji hipotesis parsial disajikan pada Tabel 9.

Berdasarkan hasil uji parsial pada Tabel 9 dapat diketahui hal berikut. Pertama, Kepemimpinan kepala sekolah secara parsial berpengaruh terhadap keefektifan sekolah. Besarnya koefisien (X1) sebesar 0,580 dengan bilangan konstanta sebesar 5,455. Berdasarkan angka-angka tersebut dapat disusun persamaan garis regresi sebagai berikut: $\hat{Y}=5,455+0,583 X 1$, artinya jika $X 1$ naik satu garis regresi maka $Y$ naik sebesar 0,583 . 
Kedua, kinerja guru secara parsial berpengaruh terhadap keefektifan sekolah. Besarnya koefisien (X2) sebesar 0,064 dengan bilangan konstanta sebesar 5,455. Berdasarkan angka-angka tersebut dapat disusun persamaan garis regresi sebagai berikut: $\hat{Y}=5,455+0,064 X 2$, artinya jika X2 naik satu garis regresi maka $\mathrm{Y}$ naik sebesar 0,064 .
Ketiga, kinerja komite sekolah secara parsial berpengaruh terhadap keefektifan sekolah. Besarnya koefisien (X3) sebesar 0,346 dengan bilangan konstanta sebesar 5,455 . Berdasarkan angka-angka tersebut dapat disusus persamaan garis regresi sebagai berikut: $\hat{Y}=5,455+0,346 X 3$, artinya jika $\mathrm{X} 3$ naik satu garis regresi maka $\mathrm{Y}$ naik sebesar 0,346.

Tabel 9. Hasil Uji Parsial

Coefficients ${ }^{a}$

\begin{tabular}{|c|c|c|c|c|c|}
\hline \multirow{2}{*}{ Model } & \multicolumn{2}{|c|}{$\begin{array}{l}\text { Unstandardized } \\
\text { Coefficients }\end{array}$} & \multirow{2}{*}{$\begin{array}{c}\begin{array}{c}\text { Standardized } \\
\text { Coefficients }\end{array} \\
\text { Beta } \\
\end{array}$} & \multirow[t]{2}{*}{$\mathrm{t}$} & \multirow{2}{*}{ Sig. } \\
\hline & B & Std. Error & & & \\
\hline (Constant) & 5,455 & 1,922 & & 2,837 & ,005 \\
\hline Kepemimpinan Kepala Sekolah &, 569 & 051 & ,583 & 11,095 & ,000 \\
\hline Kinerja Guru & 073 & , 050 & 064 & 1,448 & 150 \\
\hline Kinerja Komite Sekolah & ,376 & ,061 & ,346 & 6,210 & ,000 \\
\hline
\end{tabular}

a. Dependent Variable: KeefektifanSekolah

\section{Uji Koefisien Beta}

Pengujian ini untuk mengetahui variabel bebas yang paling dominann mempengaruhi keefektifan sekolah dengan melihat koefesiensi beta. Berdasarkan tabel 14 dapat diketahui bahwa nilai beta variabel kepemimpinan kepala sekolah (X1) mempunyai nilai paling tinggi yaitu sebesar 0,583, sehingga dapat disimpulkan bahwa variabel yang paling dominan mempengaruhi keefektifan sekolah $(\mathrm{Y})$ adalah variabel kepemimpinan kepala sekolah (X1).

Penelitian ini bertujuan untuk mengetahui: (1) pengaruh implementasi kepemimpinan kepala sekolah terhadap keefektifan seolah di sekolah dasar negeri sekecamatan Mlati Kabupaten Sleman, (2) pengaruh kinerja guru terhadap keefektifan sekolah di sekolah dasar negeri sekecamatan Mlati Kabupaten Sleman, (3) pengaruh kinerja komite sekolah terhadap terhadap keefektifan seolah di sekolah dasar negeri se-kecamatan Mlati Kabupaten Sleman, (4) pengaruh pengaruh implementasi kepemimpinan kepala sekolah, kinerja guru, dan kinerja komite sekolah terhadap keefektifan sekolah di sekolah dasar negeri se-kecamatan Mlati Kabupaten Sle- man. Berikut ini akan dibahas hasil penelitian sesuai dengan tujuan yang telah ditetapkan:

\section{Keefektifan Sekolah}

Berdasarkan data diskriptif di atas Sekolah dasar negeri se-kecamatan Mlati Kabupaten Sleman sebagian besar memiliki kecenderungan keefektifan sekolah yang tinggi. Hasil penelitian menunjukkan sebanyak 53 responden atau 35,10\% dari seluruh responden pada kategori tinggi. Keefektifan sekolah pada kategori rendah dicapai oleh 43 responden atau 28,50\% dari seluruh responden, kategori sangat tinggi hanya dicapai oleh 28 responden atau $18,50 \%$ dan 27 responden atau 17,90\% kategori sangat rendah dari seluruh responden.

Jika dihubungkan dengan literatur pada bab II terdapat kesesuaian antara hasil penelitian dengan pendapat Komariah \& Triatna yangmemperinci indikator keefektifan sekolah sebagai berikut: (1) tujuan sekolah dinyatakan dengan jelas dan spesifik, (2) pelaksanaan kepemimpinan yang kuat oleh kepala sekolah, (3) ekspektasi dari guru dan staf yang tinggi, (4) ada kerjasama kemitraan antara sekolah, orang tua siswa, dan masyarakat, (5) adanya 
iklim yang positif dan kondusif bagi siswa untuk belajar, (6) kemajuan siswa sering dimonitor, (7) menekankan kepada keberhasilan siswa dalam mencapai keterampilan aktivitas yang esensial, (8) komitmen yang tinggi dari SDM sekolah terhadap program pendidikan.

Keefektifan sekolah dasar negeri sekecamatan Mlati yang tinggi diduga karena pengaruh kepeminpinan, kinerja guru serta kinerja komite yang sudah optimal. Keefektifan sekolah yang tinggi tersebut menjadikan sekolah-sekolah dasar se-kecamatan Mlati dapat mengatasi berbagai kendala dalam proses berjalannya kegiatan belajar mengajar di sekolah. Beberapa pemecahan masalah yang terlihat menggambarkan semangat perubahan seperti dalam proses pengambilan keputusan yang diambil melibatkan semua warga sekolah dilakukan dengan demokratis dalam merencanakan, melaksanakan, dan pengawasan. Dengan cara pengambilan keputusan tersebut menjadikan segala program yang telah direncanakan dan disusun berjalan secara optimal. Berjalannya keefektifan sekolah menjadikan mantapnya dalam menyusun rencana, pelaksanaan, pengawasan, serta evaluasi program sekolah sehingga menjadikan tujuan tercapai.

Dampak unsur-unsur manajemen sekolah terurus dengan baik dari berbagai kegiatan inti di sekolah yaitu kurikulum, guru, tenaga kependidikan, peserta didik, metode, sarana prasarana, keuangan, dan lain-lain. Hal ini memberikan gambaran bahwa keefektifan sekolah dasar negeri sekecamatan Mlati cukup efektif. Sehingga segenap komponen untuk dapat menciptakan keefektifan sekolah dapat lebih meningkat. Hal ini memerlukan perhatian yang sungguh-sungguh dan serius dari segala pihak baik, kepala sekolah, guru, dan komite sekolah.

Pengaruh Implementasi Kepemimpinan Kepala Sekolah terhadap Keefektifan Sekolah

Berdasarkan hasil penelitian dapat dijelaskan bahwa sebagian besar 41,70\% menyatakan kepemimpinan kepala sekolah dasar negeri se-kecamatan Mlati pada predikat baik dan rata-rata menyatakan pengaruh bahwa kepemimpinan kepala sekolah dalam menjalankan tugasnya sebagai kepala sekolah dikategorikan tinggi dan dapat diterima oleh guru dan komite sekolah. Jika dihubungkan dengan literatur pada bab II maka terdapat kesesuaian dengan pendapat Hoy \& Miskel (2008, p. 419) mengatakan "Leadership is a process of social influence in which one person is able to enlist the aid dan support of others in the accomplishment of a common task". Kepemimpinan adalah proses pengaruh sosial di mana satu orang dapat meminta bantuan dan dukungan orang lain dalam pemenuhan tugas umum.

Kepemimpinan kepala sekolah akan berhasil jika dalam melaksanakan tugas dapat mempengaruhi anggota (guru, karyawan, dan komite sekolah) yang dipimpinnya, sebab tanpa adanya dukungan dari anggota seorang pemimpin dalam menjalankan organisasinya akan berjalan dengan pelan. Dengan adanya dukungan yang kuat dari anggota seorang pemimpin akan lebih cepat dalam mencapai tujuan yang hendak dicapainya.

Pada hasil penelitian menunjukkan keefektifan sekolah besarnya 3,231 dan setiap perubahan atau peningkatan variabel kepemimpinan kepala sekolah akan menentukan tingkat keefektifan sekolah, setiap ada kenaikan satu poin pada variabel kepemimpinan kepala sekolah berakibat naiknya skor variabel keefektifan sekolah sebesar 0,931 atau sebesar 93,10\%. Hasil dari Adjusted $R$ Sequare sebesar 0,865 atau sebesar $86,50 \%$ artinya bahwa naik atau meningkatnya variabel keefektifan sekolah dapat dijelaskan oleh kepemimpinan kepala sekolah sebesar $86,50 \%$.

Pengaruh Kinerja Guru terhadap Keefektifan Sekolah

Berdasarkan hasil penelitian dapat dijelaskan bahwa sebagian besar 81,40\% kinerja guru sekolah dasar negeri sekecamatan Mlati pada predikat baik dan rata-rata menyatakan pengaruh bahwa kinerja guru dalam menjalankan tugasnya 
sebagai tenaga pengajar dan pendidik dikategorikan tinggi dan dapat diterima oleh, kepala sekolah dan komite sekolah. Jika dihubungkan dengan literature pada bab II maka terdapat kesesuaian dengan pendapat Nawawi (2006, p. 73) yang menyatakan bahawa evaluasi kinerja diartikan sebagai kegiatan mengukur/menilai pelaksanaan pekerjaan untuk menetapkan sukses atau gagalnya seorang pekerja dalam melaksanakan tugas dan tanggung jawab di bidang kerjanya masing-masing.

Oleh karena itu kinerja guru tidaklah ditentukan oleh faktor tunggal, melainkan terdapat sejumlah faktor yang dapat mempengaruhinya. Faktor-faktor itu antara lain: fungsi kepemimpinan kepala sekolah, kinerja komite sekolah, keefektifan sekolah, dan banyak faktor yang lainnya. Hal tersebut didukung oleh pula oleh sarana prasarana pendidikan, fasilitas media pembelajaran, serta sumber belajar yang memadai baik mutu maupun jumlahnya, biaya yang mencukupi, manajemen yang tepat, serta lingkungan yang mendukung.

Pada hasil penelitian menunjukkan keefektifan sekolah besarnya 25,066 Dan setiap perubahan atau peningkatan variabel kinerja guru akan menentukan tingkat keefektifan sekolah, setiap ada kenaikan satu poin pada variabel kinerja guru, ini berakibat naiknya skor variabel keefektifan sekolah sebesar 0,778 atau 77,80\%. Hasil dari Adjusted $R$ Sequare sebesar 0,619 atau sebesar $61,90 \%$ artinya bahwa naik atau meningkatnya variabel keefektifan sekolah dapat dijelaskan oleh kepemimpinan kepala sekolah sebesar $61,90 \%$.

Pengaruh Kinerja Komite Sekolah terhadap Keefektifan Sekolah

Berdasarkan hasil penelitian dapat dijelaskan bahwa sebagian besar 93,10\% menyatakan kinerja komite sekolah dasar negeri se-kecamatan Mlati pada predikat baik dan rata-rata menyatakan pengaruh bahwa kinerja komite sekolah dalam menjalankan tugasnya sebagai mitra sekolah dikategorikan tinggi dan dapat diterima oleh, guru dan kepala sekolah. Dengan demikian warga sekolah khususnya kepala sekolah dan guru dasar se-kecamatan Mlati cukup menerima kinerja komite sekolah sebagai mitra sekolah telah menunjukkan kinerjanya secara optimal guna meningkatkan mutu dan tujuan sekolah.

Jika dihubungkan dengan bab II maka terdapat kesesuaian dengan keputusan Mendiknas (No. 044/U/2002) yang menyatakan bahwa: peran komite sekolah adalah: (1) pemberi pertimbangan (advisory agency) dalam penentuan dan pelaksanaan pendidikan di satuan pendidikan; (2) pendukung (supporting) baik yang berwujud finansial, pemikiran, maupun tenaga dalam penyelenggaran pendidikan di satuan pendidikan; (3) pengontrol (controlling agency) dalam rangka transparansi dan akuntabilitas penyelenggaraan dan keluaran pendidikan di satuan pendidikan; (4) mediator antara pemerintah (mediating) dengan masyarakat di satuan pendidikan

Pada hasil penelitian menunjukkan keefektifan sekolah besarnya 20,664 dan setiap perubahan atau peningkatan variabel kinerja komite sekolah akan menentukan tingkat keefektifan sekolah, setiap ada kenaikan satu poin pada variaabel kinerja komite sekolah berakibat naiknya skor variabel keefektifan sekolah sebesar 0,900 atau 90,00\%. Hasil dari Adjusted $R$ Sequare sebesar 0,808 atau sebesar $80,80 \%$ artinya bahwa naik atau meningkatnya variabel keefektifan sekolah dapat dijelaskan oleh kepemimpinan kepala sekolah 80,80\%.

\section{Simpulan dan Saran}

\section{Simpulan}

Berdasarkan hasil analisis data dan pembahasan dapat ditarik kesimpulan sebagai berikut. Pertama, Kepemimpinan kepala sekolah berpengaruh secara positif dan signifikan terhadap keefektifan sekolah. Ditunjukkan besarnya nilai korelasi sebesar 0,931 $(\mathrm{p}<0,05)$ atau kontribusi $\left(\mathrm{r}^{2}\right)$ sebesar $86,60 \%$. Kedua, Kinerja guru berpengaruh positif dan signifikan terhadap keefektifan sekolah. Ditunjukkan besarnya nilai korelasi sebesar 0,788 $(\mathrm{p}<0,05)$ atau kontribusi $\left(\mathrm{r}^{2}\right)$ sebesar $62,10 \%$. 
Ketiga, Pengaruh kinerja komite sekolah terhadap keefektifan sekolah. Ditunjukkan besarnya nilai korelasi sebesar 0,900 $(\mathrm{p}<0,05)$ atau kontribusi $\left(\mathrm{r}^{2}\right)$ sebesar $81,00 \%$. Keempat, Pengaruh kepemimpinan partisipatif kepala sekolah, kinerja guru, dan kinerja komite sekolah berpengaruh positif dan signifikan terhadap keefektifan sekolah. Ditunjukkan oleh besarnya nilai koefesien determinasi sebesar 0,951 ( $\mathrm{p}<$ $0,05)$ atau kontribusi $\left(R^{2}\right)$ sebesar $90,20 \%$.

Saran

Berdasarkan temuan dalam penelitian dapat disimpulkan saran sebagai berikut. Pertama, hasil penelitian ini dapat menjadi acuan untuk mengembangkan keefektifan sekolah melalui kajian kepemimpinan kepala sekolah, kinerja guru, dan kinerja komite sekolah untuk peneliti lain. Kedua, bagi kepala sekolah, guru, dan komite sekolah khususnya di kecamatan Mlati kabupaten Sleman, hasil penelitian ini agar dijadikan bahan masukan dan evaluasi internal, khususnya mengenai kepemimpinan partisipatif kepala sekolah, kinerja guru, dan kinerja komite sekolah dalam rangka meningkatkan keefektifan sekolah tempat bertugasnya.

Ketiga, bagi Dinas Pendidikan Pemuda dan Olah Raga kabupaten Sleman dapat dijadikan bahan masukan dan kajian kebijakan, khususnya yang berkaitan dengan keefektifan sekolah. Keempat, bagi para peneliti diharapkan dapat dijadikan bahan literatur, khususnya pada penelitian variabel yang sama untuk mengungkapkan temuan-temuan yang baru dalam bidang manajemen pendidikan.

\section{Daftar Pustaka}

Cheng, Y.C. (1996). School effectiveness and scholl-based management: a mechanism for development. The Falmer Press. London. Washington, D.C.
Fattah, N. (2008). Landasan manajemen pendidikan. Bandung. PT Remaja Rosdakarya. Cetakan ke- 7.

Hoy, W.K. \& Miskel, C.G. (2008). Educational administration: Theory. Research, and practice. Singapore: Mc. Graw-Hill.

Komariyah, A. \& Triatna, C. (2010). Visionary leardership: Menuju sekolah efektif. Bandung: Bumi Aksara. Cetakan ke- 4.

Lunenburg, F.C. \& Ornstein, A.C. (2000). Educational administration: Concepts and practice. Belmont: Wadswort.

Moerdiyanto. (2007). Manajemen sekolah indonesia yang efektif melalui penerapan total quality management. IMEC 2007 Proceedings 22-24 June 2007, Bayview Beach Resort, Penang, Malaysia.

Harso, M. (2010) Pengaruh kepemimpinan kepala sekolah dan kinerja guru terhadap keefektifan sekoah di smk sekabupaten pemalang. Tesis Magister. UNS

Nawawi, H. (2006). Evaluasi dan manajemen kinerja di lingkungan perusahaan dan industri. Yogyakarta: Gajah Mada University Press

Robbins, S.P. (1996). Perilaku organisasi. Jakarta: PT.Prenhallindo.

Wirawan. (2009). Evaluasi kinerja sumber daya manusia: Teori, aplikasi, dan penelitian. Jakarta: Salemba Empat.

Wuradji. (2009). The educational leadership: Kepemimpinan transformasional. Yogyakarta: Gama Media.

Depdiknas. (2007). Permendiknas RI Nomor 12, Tahun 2007, tentang Penilaian Kinerja Guru.

Depdiknas. (2007). Peraturan Pemerintah Nomor 16, Tahun 2007. tentang Standar Kompetensi Kepala Sekolah. 